\title{
TAM ARPA UNU İLE ZENGİNLEŞTİRILLMISS SPAGETTİ MAKARNANIN BESİNSEL, TEKSTÜREL VE PİŞME ÖZELLİKLERİNİN BELİRLENMESİ
}

\author{
Mehmet Köten ${ }^{1 *}$, Ayhan Atli ${ }^{2}$ \\ ${ }^{1}$ Kilis 7 Aralık Üniversitesi, Yusuf Şerefoğlu Sağılk Bilimleri Fakültesi, Beslenme ve Diyetetik Bölümü, Kilis, \\ Türkiye \\ ${ }^{2}$ Harran Üniversitesi, Ziraat Fakültesi, Gıda Mühendisliği Bölümü, Şanlıurfa, Türkiye
}

Geliş / Received: 30.06.2020; Kabul / Accepted: 19.12.2020; Online bask1 / Published online: 28.12.2020

Köten, M., Atlı, A. (2021). Tam arpa unu ile zenginleştirilmiş spagetti makarnanın besinsel, tekstürel ve pişme özelliklerinin belirlenmesi. GID A (2021) 46(1) 53-68 doi: 10.15237/gida.GD20085.

Köten, M., Atl, A. (2021). Determination of nutritional, textural and cooking properties of spaghetti pasta enriched with whole barley flour. GIDA (2021) 46(1) 53-68 doi: 10.15237/gida.GD20085.

\section{ÖZ}

Bu çalısmada, besinsel lif içeriği diğer bazı lif kaynaklarına göre daha yüksek olan arpanın makarna yapımında kullanım olanağ1 araştırlmıştır. İrmiğe tam arpa unu, değişik oranlarda (\% 0, 10, 20, 30,40 ve 50) katılmak suretiyle spagetti tipinde makarna üretilmiştir. Spagetti örnekleri bazı besinsel ve kalite özellikleri bakımından değerlendirilmiştir. Elde edilen sonuçlara göre; arpa unu ilavesi, spagetti örneklerinin protein ve kül miktarlarını kontrole göre artırmıştır. Renk özellikleri kontrole göre düşük bulunmuştur. İrmiğe arpa unu katulması ile örneklerin tüm tekstür özellikleri olumsuz etkilenmiştir. Spagetti örnekleri duyusal değerlendirmede kontrole göre daha düşük puanlar almıştır. Arpa unu katkılı spagetti örnekleri fonksiyonel bileșenler (toplam besinsel lif, $\beta$-glukan, fitik asit) bakımından fitik asit hariç kontrolden daha üstün bulunmuştur. Ayrıca örnekler element içeriği bakımından da kontrolden oldukça yüksek değerlere sahip olmuşlardır.

Anahtar kelimeler: Makarna, spagetti kalitesi, arpa, besinsel lif, fitik asit

\section{DETERMINATION OF NUTRITIONAL, TEXTURAL AND COOKING PROPERTIES OF SPAGHETTI PASTA ENRICHED WITH WHOLE BARLEY FLOUR}

\begin{abstract}
In this study, the possibility of using barley, which contains a higher dietary fiber than some other dietary fiber sources in pasta making, was investigated. Spaghetti type pasta was produced by adding whole barley flour to semolina at different ratios $(0,10,20,30,40$, and 50\%). Spaghetti samples were analyzed for some nutritional and quality properties. According to the results; addition of barley flour increased the protein and ash content of spaghetti samples compared to control. Color properties of spaghetti samples prepared with barley flour were lower than control. Texture properties of samples were negatively affected by adding barley flour. Sensory evaluation of spaghetti samples scored lower than control. Spaghetti samples with barley flour were superior in terms of functional properties (total dietary fiber, $\beta$-glucan, phytic acid) than control except phytic acid. In addition, samples had quite high values in terms of mineral matter content compared to control.
\end{abstract}

Key words: Pasta, spaghetti quality, barley, dietary fiber, phytic acid

\footnotetext{
${ }^{*}$ Yazışmalardan sorumlu yazar / Corresponding author

17: mehmetkoten@gmail.com,

(D): (+90) 5337655569

国: (+90) 3488139392
}

Mehmet Köten; ORCID no: 0000-0002-8232-8610

Ayhan Atll; ORCID no: 0000-0003-4207-6671 


\section{GİRIŞ}

Makarna tahil ürünleri içerisinde çok eskiden beri bilinen ve dünyada da en yaygin olarak tüketilen gıdalardan birisidir. Makarna bugün buğdaydan yapılan sanayi ürünleri içerisinde, üretim miktarı ve beslenmedeki önemi bakımından, ekmekten sonra gelmektedir. Makarnanın bu kadar yaygin olmasinın nedenleri, uzun süre muhafaza edilebilmesi, çeşitliliği, kolayca hazırlanması, lezzeti, besleyiciliği ve ucuz bir gıda maddesi olmasıdır. Bu nedenle, makarna ülkemizde de gelecek vaat eden gida sanayi ürünleri arasında yer almaktadır (Köten vd., 2014).

Özellikle ekonomik bakımdan gelişmiş, refah seviyesi yüksek toplumlarda bir yandan insanlarnn bedensel etkinliklerinin azalması, diğer yandan rafine edilmiş besinsel lif içeriği düşük gıdalann beslenmede yaygin bir şekilde kullanılması sonucu; kalp-damar hastalıklan, sindirim sistemi hastalıkları, aşırı şişmanlık, diyabet (şeker) ve barsak hastalıkları gibi bazı rahatsızlıkların oranı artış göstermiştir. $\mathrm{Bu}$ nedenle besinsel lifin metabolik önemi ve sağlık açısından yararı üzerine yapilan çalışmalar yoğunlaşmıştır (Gül, 2007). Günlük diyetlerinin önemli bir kısmını saflaştırilmış ürünlerden sağlayan ve ekonomik bakımdan güçlü birçok Avrupa ülkesi ve ABD'de bu tür gıdaların neden olduğu ve medeniyet hastalıkları olarak bilinen rahatsızlıkların dikkate değer bir düzeye gelmesi sonucunda özellikle son yıllarda lifli gidaların tüketimine doğru bir yönelme başlamıştur. Bunun sonucu olarak da başta kepekli ekmekler olmak üzere tam tahıl ürünlerinin pazar payları önemli düzeyde artmıştır (Sungur ve Ercan, 2003). Tam tahil; besinsel lif, mineral, vitamin, fenolik maddeler, antioksidan, nişasta, lignin ve çok az doymuş yağ asidi içermesi açısından önem taşımaktadır. $\mathrm{Bu}$ besleyici bileşenler tane içerisine düzgün bir şekilde dağılmamış olup en çok embriyo ve kepek kısmında bulunmaktadır. Ayrıca bu bileşenlerin kanser, bağırsak, kalp, yüksek kolesterol, yüksek kan basıncı, obozite ve tip 2 diyabet gibi hastalık risklerini azaltıc1 etkilerinin olduğu bilimsel çalışmalarla ortaya konmuştur (Slavin, 2004; Anonymous, 2007a; Anonymous, 2007b). Ancak öğütme sirasinda bu kisimlar ayrilmakta ve hastalıklara karş1 koruyucu etkisi olan önemli besin ögelerinin kaybı da kaçınılmaz olmaktadır.

FDA (Food and Drug Administration) tarafindan 1949 yllinda demir $(\mathrm{Fe})$ ve vitaminlerce zenginleştirmede makarnanın en önde gelen gida olduğu ifade edilmiştir. Ayrıca WHO (World Health Organization) ile FDA beslenme yönü zenginleştirilecek en iyi gıdanın makarna olduğu üzerinde görüşler de dile getirmişlerdir (Chillo vd., 2008a).

Makarna ile ilgili olarak ürün çeşitlemesi ve yeni ürün geliştirilmesi üzerine yapılan çalışmalar devam etmektedir. Makarnanın özellikle beslenme değerinin arturlması ile ilgili birçok araştırma yapılmıştır. Bu çalışmalarda genellikle makarnaya baklagil unları, kepek ve yağlı tohumlar katılıp makarnanın besin değeri artırılmaya çalışılmıştır (Gallegos-Infante vd., 2010; Petitot vd., 2010; Nasehi vd., 2009; Chillo vd., 2008b; Torres vd., 2007; Basman vd., 2006; Zhao vd., 2005). Makarnaya bunların dışında diğer tahılların katılması suretiyle de makarnanın besin değerinin arturlabileceği göz ardı edilmemelidir. Özellikle günümüzde tam tahıllı ve lifçe zengin ürünlere ilginin artmasiyla fonksiyonel makarna üretmek için yeni bir takım formülasyonlara ihtiyaç vardır.

Arpa besinsel lif içeriği bakımından oldukça zengin bir tahıl olup bu amaçla yararlanılabilecek kaynakların başında gelmektedir. Arpa başlıca hayvan yemi olarak kullanılmasının yanı sira bira ve viski üretiminde de kullanılmaktadır. Ancak, arpanın insan gidalarında katkı olarak kullanılma potansiyelinin daha çok artırılması gerekmektedir. Çünkü son yıllarda, arpada yüksek miktarda bulunan $\beta$-glukanın fonksiyonel gida katkısı olarak kullanılabileceği bilimsel çalışmalarla ortaya konmuştur. Çözünebilen bir lif olan $\beta$-glukanın koroner kalp hastalıklarını tedavi edici, kan kolesterol düzeyini düşürücü, kan şeker düzeyini dengeleyici ve oboziteyi önleyici etkisinin olduğu bildirilmektedir (Brennan ve Cleary, 2005). Bu nedenle arpanın lif içeriği düşük olan gidalara katılmas1 yukarıda sözü edilen hastalıklara yakalanma riskinin azaltılmasında pratik bir yol olarak görülmektedir. 
$\beta$-glukan gibi besinsel lifçe zengin olan arpanın sağlığa olan olumlu etkileri göz önüne alındığında makarna ürünlerinin besin değerini artırmada kullanılabileceği kaçınılmaz olmaktadır. Bu nedenle bu çalışmada tam arpa unu irmiğe ne oranda katılabileceği, ayrıca irmiğe arpa unu katılarak yapılan makarnanın bazı besinsel ve teknolojik özellikleri ile pişme kalitesi üzerine etkileri araştırılmak amaçlanmışur. Böylece hem besin değeri yüksek hem de teknolojik kalitesi iyi olan dolayısıyla besinsel lif açısından da zengin çeşnili makarna üretiminin mümkün olup olmadığı da belirlenmiştir.

\section{MATERYAL ve YÖNTEM}

\section{Materyal}

Araştırmada Filiz Gıda San. ve Tic. A.Ş. (Bolu)'den temin edilen Svevo durum buğday çeşidinin irmiği kullanılmıştır. Çalışmada materyal olarak iki sıralı Bülbül-89 arpa çeşidi kullanılmış olup Ankara Tarla Bitkileri Merkez Araştırma Enstitüsü’nün Haymana Çiftliği’nden 2008 hasat yllında temin edilmiştir.

\section{Yöntem}

\section{Materyallerin hazırlanması}

Arpa örneği laboratuvara getirildikten sonra öncelikle Midwest Welding and Machine (Germany) marka 2320N model kılçık kırıcısından geçirilerek kılçıklarından temizlenmiştir. Daha sonra Quatuor (Chopin Manifacturing) marka dokaj aletinden geçirilerek 3.5 mm'lik elek üstünde kalan (tanelerin \%97.5'i bu elek üzerinde kalmıştur) taneler alınmıştır. Çalışmada irmiğe ilave edilen tam arpa taneleri Retsch marka (tip 17.140) değirmende öğütülerek tam arpa unu elde edilmiştir. Bu aşamadan sonra arpa unu ile irmik değişik oranlarda karıştırılarak araştırmada spagetti yapımında kullanılacak karışımlar hazırlanmıstır.

\section{Makarna üretimi}

İrmiğe arpa unu \% 0-kontrol, 10, 20, 30, 40 ve 50 oranlarında katilıp 6 farklı spagetti hamur formülasyonu hazırlanmıştır. $\mathrm{Bu}$ formülasyonlardan 3 tekerrürlü olmak üzere Köksel vd. (1992) tarafindan önerilen yönteme göre Namad firması tarafindan üretilen ön yoğurucu, makarna presi ve kurutucu dolab1 kullanilarak toplam 18 spagetti tipinde makarna yapılmışır. İrmikten yapılan kontrol örneğine ve arpa unu-irmik karışımlarına ilave edilecek su miktarı (\%31 ile \%40.50 arasında değişmiştir) ön denemelerle belirlenmiştir. Su ilavesinden sonra ön yoğurucuda 15 dakika yoğurma işlemi yapilarak elde edilen hamur makarna presinde 400-600 torr vakum ve $45^{\circ} \mathrm{C}$ başlık sicaklığında şekillendirilmiştir. Başlık sıcaklığı, içerisinden su sirküle edilerek sabit tutulmaya çalışılmıştır. Şekil verilen ve askiya alınan $1.7 \mathrm{~mm}$ kalınlıktaki makarnalar kurutma dolabinda $40^{\circ} \mathrm{C}$ sicaklikta ve dolap içerisindeki nispi nemin kademeli olarak azaltılması suretiyle kurutularak, nispi nem \%60'n altına düşünceye kadar kurutma işlemi sürdürülmüsstür. Kontrol olarak üretilen spagetti örneği yaklaşık 24 saat, arpa katkılı spagetti örnekleri yaklaşık 30 saat kurutulmuştur. Kurutma işleminden sonra elde edilen makarnanın nem içeriği maksimum \%12 olmuştur. Elde edilen makarna örnekleri $30 \mathrm{~cm}$ uzunlukta kesilerek naylon torbalar içinde paketlenmiştir.

\section{Kimyasal analizler}

İrmik, arpa unu ve pişmemiş spagetti örneklerinin nem (metod 44-19), kül (metod 08-01) ve protein (metod 46-12) içeriklerinin belirlenmesinde AACC metotları kullanılmışıtı (AACC, 2000).

\section{Renk analizleri}

İrmik, arpa unu ve pişmemiş spagetti örneklerinde renk analizleri HunterLab ColorQuest, Xe model (HCL-405) renk ölçüm cihazıyla yapılmış ve değerler yine bu cihazda CIALAB ölçüm sistemine göre ifade edilmiştir. HunterLab renk skalasinda $L^{*}=0$ (siyah), $\mathrm{L}^{*}=100$ (beyaz); -a* (yeşillik), +a* (kırmızllık); -b* (mavilik), +b* (sarılık) değerleri gün 1şı̆̆1 $\left(\mathrm{D} 65 / 10^{\circ}\right)$ ayarında okunmuştur. Spagetti çubuklan $3 \mathrm{~cm}$ boyunda kesilerek 8-10 adet yan yana dizilmiş ve renk cihazının $20 \mathrm{~mm}$ lik küvetine yerleştirildikten sonra okumalar gerçekleştirilmiştir.

\section{Fonksiyonel bileşenler}

Element (Mineral) analizleri: İrmik, arpa unu ve pişmemiş spagetti örneklerinde AOAC Metot 984.27'ye göre ICP atomik emisyon spektroskopi cihazıyla belirlenmiştir (Anonymous, 1990). 
Toplam besinsel lif analizi: İrmik, arpa unu ve spagetti örneklerinde yapılmıştır. Makarna örnekleri öncelikle partikül büyüklüğü $0.5 \mathrm{~mm}$ den küçük olacak şekilde ögütülmüş ve kuru madde içerikleri tespit edilmiştir. Yöntemde toplam besinsel lif test kiti (Megazyme International Ireland Ltd., Bray Business Park, Bray, Co. Wicklow, IRELAND) kullanılmışır. Yöntem, Lee vd. (1992), Prosky vd. (1988), Prosky vd. (1992) tarafindan geliştirilen yöntemlerin modifiye edilmiş şeklidir.

$\beta$-glukan analiæi: İrmik, arpa unu ve spagetti örneklerinde gerçekleştirilmiştir. Makarna örnekleri öncelikle partikül büyüklüğü 0.5 mm'den küçük olacak şekilde öğütülmüş ve kuru madde içerikleri tespit edilmiştir. Yöntemde $\beta$ glukan test kiti (Megazyme 2/11 Ponderosa Parade, Warriewood Syndney, n.S.W., 2102 Australia) kullanılmıştır. Yöntem, McCleary and Glennie-Holmes (1985), McCleary and Codd (1991), McCleary and Mugford (1992) tarafindan geliştirilen yöntemlerin modifiye edilmiş şeklidir ve McCleary metodu olarak bilinmektedir.

Fitik asit analizi: Örneklerdeki fitik asitin $\mathrm{Fe}^{+3}$ ile çözünmez formu olan demirfitat şeklinde çöktürülüp arta kalan yani çökelmeyen $\mathrm{Fe}^{+3}$ miktarının bipyridine ile oluşturduğu rengin spektrofotometrik olarak ölçülmesi esasına dayalı bir yöntem kullanılmıştır. Bu ölçüm miktarı ile fitik asite bağlanıp çöken $\mathrm{Fe}^{+3}$ miktarı da dikkate alınarak fitik asit konsantrasyonu hesaplanmaktadır (Haug ve Lantzsch, 1983).

\section{Makarna pişme testleri}

Analizler için $4 \mathrm{~cm}$ uzunluğunda kesilen makarnalardan $25 \mathrm{~g}$ tartılarak 400 ml'lik beherde kaynamakta olan su içerisine atılmış, ağızları saat camı ile kapatılarak hot plate üzerinde zaman zaman karıştırmak suretiyle pişirilmiştir. Pişme test parametrelerinden olan hacim artışı, ağırlık artışı ve pişme kaybı analizleri Köksel vd. (2000) tarafından bildirilen metoda göre yapılırken, toplam organik madde (TOM) analizi ise D’Egidio vd. (1982)'nın bildirdiği metoda göre yapılmışur.

\section{Duyusal analiz}

Pişmiş makarnalarda duyusal analiz Köksel vd. (1992)'nin bildirdiği metoda göre gerçekleştirilmiştir. Bu yönteme göre $100 \mathrm{~g}$ spagetti kırlmadan kaynamakta olan 1 litre tuzsuz su içerisinde 13 dakika sabit süreyle pişirilmiştir. Pişirme sırasında makarnalar her 4 dakikada bir karıştırılmıştur. Süre sonunda pişen makarna gözenek açıklığ $2 \mathrm{~mm}$ ve çap $20 \mathrm{~cm}$ olan plastik elekte 15 saniye yavaşça sallanarak süzülmüştür. Süzülen makarna porselen bir tabak içerisine alınıp 6. dakikada yüzeyinin nişastalı olup olmadığına parmakla, iki cam levha arasında ezerek setliğine, içerisinde damar halinde pişmemiş kısım kalıp kalmadığına bakılmıştır. 9. dakika sonunda ise makarna elle kaldirllip bırakılarak birbirine yapışıp yapışmadığına göre kümeleşme durumu kontrol edilmiştir. Kaliteli makarna piştikten sonra birbirine yapışmamalı, başlangiçtaki şeklini ve rengini muhafaza etmeli, dayanıklı ve elastik olmalıdır. Bu yöntemde puanlama değerleri her özellik (yapışkanlık, sertlik, kümeleşme) için 0 ile 100 arasında olup, 3 uzman panelist tarafindan yapılan değerlendirmenin ortalaması verilmiştir.

\section{Tekstür analizleri}

Kuru ve pişmiş makarnalarda tekstürel analizler TA-XT2i Tekstür Analiz cihazıyla (Stable Micro Systems Ltd.,Godalming, Surrey, UK) gerçekleştirilmiştir. Kuru makarnalarda kırılma direnci testi (breaking strength) Sözer (2006)'nın bildirdiği metoda göre yapılırken, pişmiş makarnalarda tekstür profil analizleri (Texture Profile Analysis-TPA) Sozer vd. (2007) tarafindan bildirilen metoda göre yapılmıştr. Kurılma direnci analizi için üç noktalı bükme testi tekniği (Pre-test speed: $1 \mathrm{~mm} / \mathrm{s}$, test speed: $1 \mathrm{~mm} / \mathrm{s}$, post-test speed: $10 \mathrm{~mm} / \mathrm{s}$, test distance: $30 \mathrm{~mm}$, trigger value: $5 \mathrm{~g}$ ) kullanılmıştır. $5 \mathrm{~cm}$ boyunda kesilmiş makarna $2 \mathrm{~cm}$ aralıklı iki dik alüminyum bariyer üzerine yerleştirilerek orta noktasına doğru 1 $\mathrm{mm} / \mathrm{s}$ hızında kuvvet uygulanmıştır. Kırılma noktasındaki maksimum güç Newton $(\mathrm{N})$ olarak kaydedilmiştir. TPA için $10 \mathrm{~g}$ makarna $(10 \mathrm{~cm}$ boyunda kesilmiş) örneği $200 \mathrm{ml}$ saf suda 12 dakika sabit sürede pişirilmiş̧ir. Pişirilen makarnalar yavaş bir şekilde buhner hunisinde süzülüp 5 dakika soğutulmuş, daha sonra kurutma 
kağıdı ile fazla suyu alınmıştır. $\mathrm{Bu}$ şekilde hazırlanan 3 adet makarna şeridi birbirine bitişik şekilde cihazın çelik tablasına yerleştirilmiş ve analize başlanmıştır. TPA, P/36R donanımı ile (Pre-test speed: $3 \mathrm{~mm} / \mathrm{s}$, test speed: $1 \mathrm{~mm} / \mathrm{s}$, post-test speed: $1 \mathrm{~mm} / \mathrm{s}$, test distance: $1 \mathrm{~mm}$, triger type: Auto (Force), trigger force: $5 \mathrm{~g}$ ) gerçekleştirilmiştir. Elde edilen kuvvet-zaman eğrisinden sertlik, yapışkanlık, esneklik ve çiğnenebilirlik parametreleri belirlenmiştir.

\section{İstatistiksel analizler}

Sonuçların istatistiksel olarak değerlendirilmesinde IBM SPSS Statistics 23 paket programı kullanılmıştır. Sonuçlar için tek yönlü ANOVA istatistik modeli uygulanarak grup ortalamaları arasındaki fark belirlenmiş ve farkliliklar $P \leq 0.05$ düzeyinde Duncan testi ile belirlenmiştir.

\section{SONUÇ ve TARTIŞMA}

Spagetti üretiminde kullanılan irmik ve tam arpa ununun özellikleri

Hammadde özellikleri son ürün kalitesini doğrudan etkilemektedir. Spagetti üretiminde hammadde olarak kullanilan irmik ve tam arpa ununun kimyasal, besinsel ve renk özelliklerine ait değerler Çizelge 1'de verilmiştir.

Çizelge 1. Hammadde özellikleri

Table 1. Raw material properties

\begin{tabular}{lcc}
\hline $\begin{array}{l}\text { Özellikler } \\
\text { Properties }\end{array}$ & $\begin{array}{c}\text { Irmik } \\
\text { Semolina }\end{array}$ & $\begin{array}{c}\text { Tam arpa unu } \\
\text { Whole barley flour }\end{array}$ \\
\hline Kül $(\%)^{\dagger}$ & $0.86 \pm 0.03$ & $1.96 \pm 0.13$ \\
Ash (\%) & & \\
Protein $(\%)^{\dagger}$ & $11.40 \pm 0.35$ & $15.19 \pm 0.30$ \\
Protein $\%)^{\dagger}$ & & \\
Toplam besinsel lif $(\%)^{\dagger}$ & $2.36 \pm 0.06$ & $23.61 \pm 0.13$ \\
Total Dietary Fiber $\%)^{\dagger}$ & & \\
Fitik asit $(\mathrm{mg} / \mathrm{g})^{\dagger}$ & $1.82 \pm 0.06$ & $3.52 \pm 0.10$ \\
Phytic acid $(\mathrm{mg} / \mathrm{kg})^{\dagger}$ & & \\
$\beta$-glukan $(\%)^{\dagger}$ & $0.19 \pm 0.01$ & $3.85 \pm 0.00$ \\
$\beta$-glucan $\%)^{\dagger}$ & $85.98 \pm 0.05$ & $83.00 \pm 0.15$ \\
$\mathrm{~L}^{*}$ & $1.43 \pm 0.01$ & $1.49 \pm 0.04$ \\
$\mathrm{a}^{*}$ & $22.12 \pm 0.06$ & $13.50 \pm 0.01$ \\
$\mathrm{~b}^{*}$ & $120.00 \pm 0.35$ & $188.00 \pm 2.76$ \\
$\mathrm{Na}(\mathrm{mg} / \mathrm{kg})$ & $2071.00 \pm 14.85$ & $3405.00 \pm 44.55$ \\
$\mathrm{~K}(\mathrm{mg} / \mathrm{kg})$ & $254.00 \pm 18.03$ & $274.00 \pm 8.27$ \\
$\mathrm{Ca}(\mathrm{mg} / \mathrm{kg})$ & $421.00 \pm 6.58$ & $870.00 \pm 33.57$ \\
$\mathrm{Mg}(\mathrm{mg} / \mathrm{kg})$ & $18.60 \pm 0.94$ & $29.50 \pm 1.22$ \\
$\mathrm{Fe}(\mathrm{mg} / \mathrm{kg})$ & $3.05 \pm 0.66$ & $3.00 \pm 0.59$ \\
$\mathrm{Cu}(\mathrm{mg} / \mathrm{kg})$ & $14.00 \pm 0.10$ & $19.00 \pm 1.51$ \\
$\mathrm{Zn}(\mathrm{mg} / \mathrm{kg})$ & & \\
\hline $\mathrm{K}$ & &
\end{tabular}

†uru maddede hesaplanmıştır

${ }^{\dagger}$ Calculated in dry matter

Üretimde kullanılan irmiğin kül ve protein değerleri sırasıyla $\% 0.86$ ve $\% 11.40$ olarak tespit edilmiş ve bu değerlerin Türk G1da Kodeksi İmik Tebliği (Anonymous, 2002b)'nde belirtilen değerler açısından uygun olduğu görülmüştür. İrmikte ve son ürün olan makarnada açk ve parlak bir sarı renk istenilen bir özelliktir ve makarnalık buğday bütün buğdaylar arasında yeterli miktarda ve doğal sarı renk pigmenti (karotenler ve ksantofiller) içermesi nedeniyle eşsizdir (Hailu and Merker, 2008). İrmik örneğinin renk değerlerine bakıldığında özellikle 
makarna için önem taşıyan $b^{*}$ değerinin istenen düzeyde olduğu görülmektedir (Çizelge 1). Coşkun vd. (2010), Güneydoğu Anadolu Bölgesi'nde yetiştirilen 6 makarnalık buğday çeşidine ait irmiklerde b değerini 21.12 ile 25.88 arasında bulmuşlardır. Madenci (2017), makarna üretiminde kullandığ buğday irmiğine ait $\mathrm{L}^{*}, a^{*}$ ve b* değerlerini sirasiyla $88.11,-1.73$ ve 22.53 olarak bildirmiştir. İrmikte saptanan toplam besinsel lif, fitik asit ve $\beta$-glukan içeriklerinin arpa ununda saptanan değerlerden düşük olduğu görülmüştür. İrmikte belirlenen toplam besinsel lif ve $\beta$-glukan değerleri daha önce yapılan çalışmalarda (Cleary ve Brennan, 2006; Marconi vd., 2000; Marconi vd., 1999) bildirilen değerlere yakın bulunmuştur. Çizelge 1'de görülebileceği gibi irmik örneğinde potasyum (K) en fazla, bakır (Cu) en az miktarda saptanmıştır. Matsuo (1996), irmikte potasyum miktarının $1976 \mathrm{mg} / \mathrm{kg}$, magnezyum miktarının $690 \mathrm{mg} / \mathrm{kg}$ ve kalsiyum miktarının $190 \mathrm{mg} / \mathrm{kg}$ olduğunu bildirmiştir. Köse ve Mut (2019), on üç farklı arpa çeşidinin element içeriklerini belirledikleri çalışmalarında K miktarını 3166.7$5483.2 \mathrm{mg} / \mathrm{kg}$, Ca miktarın $334.6-802.7 \mathrm{mg} / \mathrm{kg}$, $\mathrm{Na}$ miktarını 409.2-670.2 ve Mg miktarını 853.8$1604.7 \mathrm{mg} / \mathrm{kg}$ olarak belirlemişlerdir. Bu literatür sonuçlarıyla karşılaştırıldığında irmik ve arpa ununda bulduğumuz sonuçların yaklaşı olarak benzerlik gösterdiği söylenebilir.

Çizelge 1'den de görülebileceği gibi arpa ununun tüm kimyasal ve besinsel içeriklerinin yanı sıra mineral içeriklerinin de buğday irmiğinden oldukça yüksek olduğu görülmüştür. Özellikle toplam besinsel lif ve $\beta$-glukan değerleri arpa ununda sirasiyla $\% 23.61$ ve $\% 3.85$ olarak saptanırken buğday irmiğinde $\% 2.36$ ve $\% 0.19$ olarak saptanmıştır. Yapılan bir çalışmada, kavuzsuz arpa veya kabuğu soyulmuş arpa tanesinin \%11-20 arasında toplam besinsel lif içerdiği, bunun \%11-14'ünün çözünemeyen besinsel lif ve \% 3-10'unun çözünür besinsel lif olduğu rapor edilmiştir. Aynı araştırmacılar tam arpa tanesinin \%4.0-9.0 arasinda $\beta$-glukan içerdiğini bildirmişlerdir (Baik ve Ulrich, 2008). Panfili vd. (2008)'in yaptı̆̆ bir çalışmada kabuğu soyulmamıs arpada $\beta$-glukan değerini \% 4.34 olarak bulmuşlardır. Yeung ve Vasanthan (2001), arpada kabuk soyma sayısına bağlı olarak $\beta$-glukan değerinin arttı̆̆ını bildirdikleri çalışmalarında kabuğu soyulmamıs arpada $\beta$-glukan değerini \% 5.9 olarak saptamışlardır. Spagetti üretiminde katk1 olarak kullanilan tam arpa ununda belirlenen kül (\%1.96) ve protein (\%15.19) değerlerinin de literatürde (Yalçın ve Çelik, 2006; Helm ve de Francisco, 2004) bildirilen değerlerle uyum içerisinde olduğu bulunmuştur. Arpa ununun renk sonuçlarına bakıldığında $L^{*}$ ve $a^{*}$ değerleri açısından irmikle benzer olduğu ancak $b^{*}$ değeri bakımından irmikten daha az sarı olduğu söylenebilir. Tahıl tanelerinin temel depo fosfor bileşeni olan fitik asit değeri Çizelge 1 incelendiğinde arpa ununda $3.52 \mathrm{mg} / \mathrm{g}$ olarak tespit edilirken, irmikte $1.82 \mathrm{mg} / \mathrm{g}$ olarak tespit edilmiştir. Yapılan bir çalışmada, fitik asitin arpanın alöron tabakasinda ve embriyosunda yoğunlaştuğ1 saptanmıştır (O’Dell vd., 1972). Dai vd. (2007), 2 yll 7 lokasyonda 100 arpa genotipinde yaptukları çalışmada fitik asit içeriğinin birinci yılda $1.19 \mathrm{mg} / \mathrm{g}$ ile $8.72 \mathrm{mg} / \mathrm{g}$ arasında değiştiğini, ikinci yllda ise $1.00 \mathrm{mg} / \mathrm{g}$ ile $6.19 \mathrm{mg} / \mathrm{g}$ arasında değiştiğini bildirmişlerdir. Köksel vd. (1999), prosesin ve pişirmenin arpa bulgurunun kimyasal kompozisyonuna etkisi üzerine yaptıkları çalışmalarında Bülbül 89 arpa çeşidinde element içeriklerini sırasıyla $\mathrm{Fe}$ (24 ppm), Cu (4.9 ppm), Zn (22 ppm), Mn (83 ppm), $\mathrm{Ca}(320 \mathrm{ppm})$ ve $\mathrm{Mg}$ (840 ppm) olarak belirlemişlerdir. Çizelge 1 incelendiğinde tam arpa ununda bulunan element içeriklerinin bu çalışmayla yaklaşı uyum içinde olduğu söylenebilir.

\section{Spagetti örneklerinin kimyasal, fonksiyonel ve renk özellikleri}

Farklı oranlarda tam arpa unu ilaveli pişmemiş makarnaların ve kontrol makarnasının kül ve protein miktarı sonuçları Çizelge 2'de gösterilmiştir. Buna göre, örneklerin kül değerleri arpa unu ilave oranının artısına bağlı olarak yükselmiştir. Değerlerdeki yükseliş istatistiksel olarak da önemli bulunmuştur $\left(\begin{array}{ll}P & \leq 0.05\end{array}\right)$ Pişmemiş tüm makarna örneklerinde kül değerleri \%0.88-\%1.51 arasında değişmiş ve en düşük değer $\% 0.88$ ile kontrol örneğinde saptanmıştr. 
Çizelge 2. Spagetti örneklerinin kimyasal, fonksiyonel ve renk özelliklerił Table 2. Chemical, functional and color properties of spaghetti samples

\begin{tabular}{|c|c|c|c|c|c|c|}
\hline \multirow{2}{*}{$\begin{array}{l}\text { Özellikler } \\
\text { Properties }\end{array}$} & \multicolumn{6}{|c|}{$\begin{array}{l}\text { Tam arpa unu oranı }(\%) \\
\text { Whole barley flour ratio (\%) }\end{array}$} \\
\hline & 0 & 10 & 20 & 30 & 40 & 50 \\
\hline $\begin{array}{l}\text { Kül }(\%)^{\dagger} \\
\text { Ash }(\%)^{\dagger}\end{array}$ & $0.88 \pm 0.06^{\mathrm{e}}$ & $1.02 \pm 0.04 \mathrm{~d}$ & $1.14 \pm 0.08^{c}$ & $1.29 \pm 0.07 \mathrm{~b}$ & $1.42 \pm 0.05^{a}$ & $1.51 \pm 0.05^{a}$ \\
\hline $\begin{array}{l}\text { Protein }(\%)^{\dagger} \\
\text { Protein }(\%)^{\dagger}\end{array}$ & $12.43 \pm 0.20^{\mathrm{d}}$ & $12.67 \pm 0.11^{\mathrm{cd}}$ & $12.85 \pm 0.08^{\mathrm{bc}}$ & $12.90 \pm 0.08^{\mathrm{ab}}$ & $13.00 \pm 0.05^{\mathrm{ab}}$ & $13.11 \pm 0.13^{\mathrm{a}}$ \\
\hline $\begin{array}{l}\text { Toplam besinsel lif }(\%)^{\dagger} \\
\text { Total dietary fiber }(\%)^{\dagger}\end{array}$ & $1.60 \pm 0.00^{\mathrm{f}}$ & $3.70 \pm 0.44 \mathrm{e}$ & $4.59 \pm 0.50^{\mathrm{d}}$ & $6.62 \pm 0.57 \mathrm{c}$ & $8.18 \pm 0.34^{b}$ & $9.69 \pm 0.60^{a}$ \\
\hline $\begin{array}{l}\beta \text {-glukan }(\%)^{\dagger} \\
\beta \text {-glucan }(\%)^{\dagger}\end{array}$ & $0.18 \pm 0.05^{f}$ & $0.60 \pm 0.09 \mathrm{e}$ & $1.11 \pm 0.01 \mathrm{~d}$ & $1.58 \pm 0.10 \mathrm{c}$ & $2.19 \pm 0.02^{\mathrm{b}}$ & $2.44 \pm 0.06^{a}$ \\
\hline $\begin{array}{l}\text { Fitik asit }(\mathrm{mg} / \mathrm{g})^{\dagger} \\
\text { Phytic } \text { acid }^{*}(\mathrm{mg} / \mathrm{kg})^{\dagger}\end{array}$ & $1.23 \pm 0.03^{\mathrm{f}}$ & $1.36 \pm 0.03^{\mathrm{e}}$ & $1.43 \pm 0.07^{\mathrm{d}}$ & $1.55 \pm 0.03^{c}$ & $1.61 \pm 0.01^{\mathrm{b}}$ & $1.74 \pm 0.03^{\mathrm{a}}$ \\
\hline $\mathrm{L}^{*}$ & $50.98 \pm 0.51^{\mathrm{a}}$ & $45.33 \pm 0.60^{\mathrm{b}}$ & $43.58 \pm 0.30^{\mathrm{b}}$ & $40.30 \pm 2.21 \mathrm{c}$ & $39.04 \pm 0.55^{c}$ & $38.00 \pm 0.48^{c}$ \\
\hline$a^{*}$ & $2.43 \pm 0.12^{c}$ & $4.99 \pm 0.64 \mathrm{~b}$ & $6.12 \pm 0.30^{\mathrm{b}}$ & $7.29 \pm 0.51 \mathrm{a}$ & $7.34 \pm 0.17 \mathrm{a}$ & $7.35 \pm 0.38^{a}$ \\
\hline $\mathrm{b}^{*}$ & $29.93 \pm 0.50^{a}$ & $26.81 \pm 1.15^{b}$ & $24.25 \pm 1.17 \mathrm{c}$ & $21.48 \pm 1.43^{\mathrm{d}}$ & $19.48 \pm 1.94 \mathrm{e}$ & $17.56 \pm 2.44^{\mathrm{f}}$ \\
\hline
\end{tabular}

¥Aynı satırda farklı harflerle gösterilen ortalamalar arasındaki fark istatistiksel olarak önemlidir $(P \leq 0.05)$

The difference between the means shown with different letters on the same line is statistically significant $(P \leq 0.05)$

tKuru maddede hesaplanmışur

Calculated in dry matter

Makarnaların protein miktarlanı incelendiğinde, kontrol örneğinin kuru madde üzerinden protein miktar1 \%12.43 olarak belirlenirken, tam arpa unu ilaveli pişmemiş makarnalann kuru madde üzerinden protein miktarlar1 \%12.67-13.11 arasında değişmiştir (Çizelge 2). Çizelgeden de görüldüğü gibi arpa unu ilave oranının artısına bağlı olarak pişmemiş makarnaların protein miktarlarında artıs olmuştur. Arpa unu ilaveli makarnalarda en yüksek protein miktarı $\% 50$ arpa unu ilaveli örnekte saptanırken en düşük protein değeri \%10 arpa unu ilaveli örnekte saptanmıştır. Kontrol ve arpa unu ilaveli pişmemiş makarnaların protein değerleri arasındaki fark istatistiksel olarak da önemli bulunmuştur ( $P$ $\leq 0.05$ ). Köten vd. (2014), Türkiye'de üretilen makarnaların kimyasal kompozisyonu üzerine yaptıkları çalışmalarında, makarna örneklerinde kül miktarını \%0.69-1.18 ve protein miktarını da $\% 9.53-11.73$ arasında tespit etmişlerdir. Türk Gida Kodeksi Makarna Tebliği'ne göre, sade ve zenginleştirilmiş makarnaların protein miktarının kuru madde üzerinden en az $\% 10.50$, tam buğday makarnasinin en az \%11.0, tam buğday makarnasının kül miktanının ise kuru madde üzerinden en çok \%2.0 olması gerekmektedir (Anonymous, 2002a). Bu araştırmada, tüm makarna örneklerinin bu iki parametre açısından Türk Gıda Kodeksi Makarna Tebliği'ne uygun olduğu görülmüştür. Marconi vd. (2000)'nin arpa soyma yan ürünlerini kullanarak $\beta$-glukan miktarı bakımından zenginleştirilmiş makarna çalışmasında, kontrol makarnasında protein miktarını \%12.20, zenginleştirilmiş makarnalarda protein miktarını \%15.3-18.5 arasında, kül miktarlarını ise kontrol makarnasında \%0.73, zenginleştirilmiş makarnalarda \%1.69-1.82 arasında tespit etmişlerdir.

Fonksiyonel bileşen olarak nitelendirilebilen toplam besinsel lif, $\beta$-glukan ve fitik asit içeriği bakımından makarna örneklerinde yapılan analiz sonuçları Çizelge 2'de sunulmuştur. Makarna örneklerinde toplam besinsel lif değerleri \%1.06 ile $\% 9.69$ arasında değissirken, $\beta$-glukan ve fitik asit değerleri sırasiyla \%0.18-2.44 ve $1.23-1.74 \mathrm{mg} / \mathrm{g}$ aralıklarında değişmiştir. Makarna formülasyonuna tam arpa unu ilavesi tüm katk1l örneklerin besinsel lif, $\beta$-glukan ve fitik asit miktarlarında kontrol örneğine göre önemli bir 
artışa neden olmuştur $(P \leq 0.05)$. Arpa unu ilave oranı arttıkça makarna örneklerinde bu parametrelerin tümünde artş olmuştur. En yüksek toplam besinsel lif (\%9.69), $\beta$-glukan $(\% 2.44)$ ve fitik asit $(1.74 \mathrm{mg} / \mathrm{g})$ içerikleri $\% 50$ arpa unu ilaveli makarna örneğinde tespit edilmiştir. Fitik asitin bitki için çok önemli fonksiyonları olmasına karşın insan vücudunda bir takım olumsuzlukları bulunmaktadır. Bunların başında $\mathrm{Ca}, \mathrm{Fe}, \mathrm{Zn}$, Mn gibi bazı esansiyel minerallerle kompleks oluşturarak bunların absorpsiyonunu engellemesi gelir. Ayrica fosforun büyük bir kısmını fitat fosforu olarak bünyesinde bağlayarak veya bazı amino asitlerle interaksiyona girerek de etkili olabilmektedir (Dendougui ve Schwedt, 2004; Egli vd., 2004; Hurrell, 2004). Bu açıdan bakıldığında gıdalarda miktarının düşük olması istenir. Ancak son yıllarda fitik asidin insan sağllğı üzerindeki etkisi konusunda yapılan çalışmalar fitik asidin antikanserojen ve antioksidan etkisi nedeniyle pozitif etkilere de sahip olduğunu göstermiştir (Tolay vd., 2005). Bashir vd. (2012), yağ1 alınmış soya unu ile nohut unu katkilı makarna çalışmalarında üretilen makarnalardaki diyet lif oranlannı $\% 4.04$ ile $\% 4.30$ arasinda belirlemişlerdir. Güvendi (2011) besinsel lif ve antioksidanca zengin tahillardan geleneksel yöntem ile erişte üretimi üzerine yaptı̆̆ tez çalışmasında, kontrol eriştesinde toplam besinsel lif miktarını \%5.64, erişte formülasyonuna kavuzsuz arpa unu ilave ederek (\%25, 50, 100 oranlarında) yaptığı eriştelerde toplam besinsel lif miktarlarını sırasıly $\% 5.6, \% 6.19$ ve $\% 7.28$ olarak belirlemiştir. Aynı araştırmada, $\beta$-glukan miktarları kavuzsuz arpa unu ilaveli eriştelerde sirasiyla $\% 1.25, \quad \% 2.02$ ve $\% 2.66$ olarak saptanmıştır. Yapılan diğer bir çalışmada kontrol makarna örneğinde $\beta$-glukan miktarı \%0.29 olarak bulunurken $\% 30$ ve $\% 50$ oraninda arpa unu ile zenginleştirilmiş makarnalarda sırasıyla $\% 2.93$ ve \%5.00 olarak bulunmuştur (De Paula vd., 2017). Çalışmamızda üretilen makarnaların toplam diyet lif ve $\beta$-glukan miktarları bu çalışmalarla benzer bulunmuştur.

\section{Spagetti örneklerinin element içerikleri}

Arpa mineral madde bakımından oldukça zengin olup, insan ve hayvan beslenmesinde hayati bir öneme sahiptir. Mineral maddeler doku ve organların yapisına katılarak, vücutta asit baz dengesini ve osmotik dengeyi düzenlerler. Ayrıca, bazı vitamin, hormon ve enzimlerin yapisina katilarak metabolik faaliyetlerin yerine getirilmesinde, kas ve sinirlerin uyarilmasinda görev alırlar. Genetik farklılıklar ve çevre faktörleri arpanın mineral madde içeriğine etki eden iki ana temel faktördür (Köse ve Mut, 2019). Arpa unu katkılı spagetti örneklerinin element içerikleri Çizelge 3'te verilmiştir. Çizelge incelendiğinde arpa unu ilave oranının artışına bağlı olarak değerlerde artış gözlenmiştir. Bu artış istatistiksel olarak da önemli bulunmuştur $(P$ $\leq 0.05$ ). Spagetti örneklerinde en fazla bulunan elementin $\mathrm{K}$ olduğu, en az bulunan elementin ise $\mathrm{Cu}$ olduğu çizelgeden de görülmektedir. En düşük K miktar1 2089 mg $/ \mathrm{kg}$ ile kontrol örneğinde tespit edilirken, en yüksek değer $3726 \mathrm{mg} / \mathrm{kg}$ ile $\% 50$ arpa unu ilaveli makarna örneğinde tespit edilmiştir. Bakla ve kinoa unu ilaveli misır makarnalarının kalite özelliklerinin araştırıldığı bir çalışmada kontrol makarna örneğinde $\mathrm{Zn}$ ve Fe miktarı sirasiyla $5.4 \mathrm{mg} / \mathrm{kg}$ ve $39.0 \mathrm{mg} / \mathrm{kg}$ olarak bulunmuştur. Aynı çalışmada \%30 bakla unu ilaveli makarna örneğinde Zn miktar1 $17.3 \mathrm{mg} / \mathrm{kg}$, Fe miktar1 $84.8 \mathrm{mg} / \mathrm{kg}$; \%20 kinoa unu ilaveli makarna örneğinde $\mathrm{Zn}$ miktarı $15.4 \mathrm{mg} / \mathrm{kg}$ ve Fe miktar1 $58.0 \mathrm{mg} / \mathrm{kg}$ olarak tespit edilmiştir (Gimenez vd., 2016).

Silva vd. (2016) tarafindan yapılan çalışmada kahverengi pirinç ve mısır unu karışımlanı ile hazırlanan glutensiz makarna örneklerinin $\mathrm{Ca}$ içerikleri 59.1-84.1 mg/kg, Fe içerikleri 14.4-19.5 $\mathrm{mg} / \mathrm{kg}, \mathrm{Mg}$ içerikleri $775-1070 \mathrm{mg} / \mathrm{kg}$ ve K içerikleri 1643.1-2008.0 $\mathrm{mg} / \mathrm{kg}$ olarak saptanmıştur. Çalışmamızda tam arpa unu ilaveli makarnalarda belirlenen element içeriklerinin literatürde bildirilen değerlere benzer ve yakın olduğu görülmüştür.

\section{Spagetti örneklerinin pişme özellikleri}

Tam arpa unu ilavesi ile değişik formülasyonlarda elde edilen makarnaların hacim artışı, ağırlık artışı, pişme kaybı ve toplam organik madde (TOM) gibi pişme kalitesi özelliklerine ilişkin sonuçlar Çizelge 4'te verilmiştir. 
Çizelge 3. Spagetti örneklerinin element içerikleri* Table 3. Element contents of spaghetti samples*

\begin{tabular}{|c|c|c|c|c|c|c|}
\hline \multirow{2}{*}{$\begin{array}{l}\text { Özellikler } \\
\text { Properties }\end{array}$} & \multicolumn{6}{|c|}{$\begin{array}{l}\text { Tam arpa unu oran1 (\%) } \\
\text { Whole barley flour ratio (\%) }\end{array}$} \\
\hline & 0 & 10 & 20 & 30 & 40 & 50 \\
\hline $\mathrm{Na}(\mathrm{mg} / \mathrm{kg})$ & $123.33 \pm 1.53^{\mathrm{f}}$ & $140.33 \pm 2.52^{\mathrm{e}}$ & $158.17 \pm 1.26^{\mathrm{d}}$ & $178.67 \pm 2.52^{\mathrm{c}}$ & $197.50 \pm 2.29^{\mathrm{b}}$ & $217.33 \pm 3.51^{a}$ \\
\hline $\mathrm{K}(\mathrm{mg} / \mathrm{kg})$ & $2089.00 \pm 9.00^{\mathrm{f}}$ & $2403.00 \pm 7.00^{\mathrm{e}}$ & $2740.00 \pm 12.49^{\mathrm{d}}$ & $3049.00 \pm 46.36^{c}$ & $3412.00 \pm 18.52^{\mathrm{b}}$ & $3726.00 \pm 38.79^{a}$ \\
\hline $\mathrm{Ca}(\mathrm{mg} / \mathrm{kg})$ & $271.00 \pm 3.00^{e}$ & $292.67 \pm 2.52^{\mathrm{e}}$ & $314.33 \pm 2.08^{\mathrm{d}}$ & $349.00 \pm 2.65^{c}$ & $372.00 \pm 2.65^{\mathrm{b}}$ & $399.67 \pm 1.53^{\mathrm{a}}$ \\
\hline $\mathrm{Mg}(\mathrm{mg} / \mathrm{kg})$ & $430.33 \pm 1.53^{\mathrm{f}}$ & $515.67 \pm 2.08^{\mathrm{e}}$ & $601.67 \pm 3.06^{\mathrm{d}}$ & $690.33 \pm 2.52^{c}$ & $782.67 \pm 3.06^{\mathrm{b}}$ & $865.00 \pm 4.58^{a}$ \\
\hline $\mathrm{Fe}(\mathrm{mg} / \mathrm{kg})$ & $19.52 \pm 0.11^{\mathrm{d}}$ & $27.80 \pm 1.26^{\mathrm{c}}$ & $30.66 \pm 2.52^{c}$ & $36.83 \pm 1.04^{\mathrm{b}}$ & $40.16 \pm 0.76^{a}$ & $43.30 \pm 1.53^{\mathrm{a}}$ \\
\hline $\mathrm{Cu}(\mathrm{mg} / \mathrm{kg})$ & $3.10 \pm 0.03^{\mathrm{f}}$ & $3.42 \pm 0.03^{\mathrm{e}}$ & $3.73 \pm 0.02^{\mathrm{d}}$ & $4.05 \pm 0.03^{c}$ & $4.37 \pm 0.02^{\mathrm{b}}$ & $4.68 \pm 0.02^{\mathrm{a}}$ \\
\hline $\mathrm{Zn}(\mathrm{mg} / \mathrm{kg})$ & $14.01 \pm 0.02^{\mathrm{f}}$ & $16.27 \pm 0.25^{\mathrm{e}}$ & $17.95 \pm 0.05^{\mathrm{d}}$ & $19.76 \pm 0.05^{c}$ & $21.64 \pm 0.05^{\mathrm{b}}$ & $23.55 \pm 0.06^{\mathrm{a}}$ \\
\hline
\end{tabular}

*Aynı satırda farklı harflerle gösterilen ortalamalar arasındaki fark istatistiksel olarak önemlidir $(P \leq 0.05)$

*The difference between the means shown with different letters on the same line is statistically significant $(P \leq 0.05)$

Çizelge 4. Spagetti örneklerinin pişme özellikleri*

Table 4. Cooking properties of spaghetti samples*

\begin{tabular}{|c|c|c|c|c|c|c|}
\hline \multirow{2}{*}{$\begin{array}{l}\text { Özellikler } \\
\text { Properties }\end{array}$} & \multicolumn{6}{|c|}{$\begin{array}{l}\text { Tam arpa unu oranı }(\%) \\
\text { Whole barley flour ratio }(\%)\end{array}$} \\
\hline & 0 & 10 & 20 & 30 & 40 & 50 \\
\hline $\begin{array}{l}\text { Hacim artışı }(\%) \\
\text { Volume increase (\%) }\end{array}$ & $317.23 \pm 23.47^{\mathrm{a}}$ & $317.07 \pm 14.69^{a}$ & $305.55 \pm 10.02^{\mathrm{ab}}$ & $305.05 \pm 18.07^{\mathrm{ab}}$ & $294.55 \pm 14.82^{\mathrm{ab}}$ & $280.55 \pm 10.02^{\mathrm{b}}$ \\
\hline $\begin{array}{l}\text { Ağ1rlik artışı (\%) } \\
\text { Weight increase (\%) }\end{array}$ & $242.55 \pm 1.73^{\mathrm{a}}$ & $231.70 \pm 6.97 \mathrm{ab}$ & $220.82 \pm 5.83 \mathrm{bc}$ & $216.83 \pm 5.74 \mathrm{bcd}$ & $209.58 \pm 3.42^{\mathrm{cd}}$ & $204.65 \pm 5.62^{\mathrm{d}}$ \\
\hline $\begin{array}{l}\text { Pişme kaybı (\%) } \\
\text { Cooking loss (\%) }\end{array}$ & $7.57 \pm 0.19 \mathrm{~d}$ & $8.24 \pm 0.14 c$ & $8.43 \pm 0.13 \mathrm{bc}$ & $8.74 \pm 0.14^{b}$ & $9.16 \pm 0.14^{a}$ & $9.28 \pm 0.22^{\mathrm{a}}$ \\
\hline $\begin{array}{l}\operatorname{TOM}(\%)^{* *} \\
\operatorname{TOM}(\%)^{* *}\end{array}$ & $1.37 \pm 0.04 \mathrm{~d}$ & $1.43 \pm 0.05^{c}$ & $1.45 \pm 0.05^{c}$ & $1.50 \pm 0.05^{b c}$ & $1.62 \pm 0.02^{\mathrm{ab}}$ & $1.70 \pm 0.03^{\mathrm{a}}$ \\
\hline
\end{tabular}

${ }^{*}$ Aynı satırda farklı harflerle gösterilen ortalamalar arasındaki fark istatistiksel olarak önemlidir $(P \leq 0.05)$

*The difference between the means shown with different letters on the same line is statistically significant $(P \leq 0.05)$

**Toplam organik madde

${ }^{*}$ Total organic matter

Spagetti örneklerinin hacim artışı değerleri \%280.55 ile \%317.23 arasında değişmiştir. Arpa ilave oranının hacim artşs değerleri üzerine etkisi istatistiksel olarak önemli bulunmuştur $(P \leq 0.05)$. Katkı oranının artışına bağlı olarak hacim artışı değerlerinde düşüş gözlenmiştir. En yüksek hacim artış1 değerine (\%317.23) kontrol örneği sahip olurken arpa unu ilaveli spagetti örneklerinde en yüksek değere (\%317.07) \%10 arpa unu ilaveli spagetti örneği sahip olmuştur. En düşük hacim artş̧ değeri \%280.55 ile \%50 arpa unu ilaveli spagetti örneği sahip olmuştur. Çizelge 4'ten de görülebileceği gibi arpa katkilı spagetti örneklerinin su absorpsiyon değerleri \%231.5 ile $\% 242.55$ arasında değişmiş ve en yüksek ağırlık artış1 değeri kontrol örneğinde saptanmıştır. Katkılı makarnalarda ağırlık artışı kontrole göre düşük bulunmuştur. Ağırlık artısı arpa unu ilave oranı arttıkça azalış göstermiş ve bu durum istatistiksel olarak da önemli bulunmuştur ( $P$ 
$\leq 0.05$ ). Isısal işlemler protein moleküllerinin denatürasyonuna (molekül ağlarının açılmasına) sebep olmaktadır. Bu yüzden pişirme sırasında denatüre olan protein moleküllerinin içindeki fonksiyonel bileşenler açığa çıkarak protein molekülünün yüzey hidrofobikliğini artırmaktadırlar (Bergman vd., 1994). Makarna örneklerindeki ağırlık artş̧ı değerlerinin düşmesinin bu durumdan kaynaklandığ1 düşünülmektedir. Yani pişirme ile arpa protein moleküllerinin su çekme kapasitesinde bir düşüş olmuş ve dolayısıyla ağırlık artışında azalma görülmüştür. Pınarlı vd. (2004)'nın buğday embriyosu katkılı makarna üzerine yaptıkları çalışmada embriyo katkılı örneklerde ağırlık artışı kontrol örneğine göre daha düşük bulunmuştur. Yapılan diğer çalışmalarda (Gallegos-Infante vd., 2010; Petitot vd., 2010; Wood, 2009) da benzer sonuçlar bildirilmiştir. Suya geçen madde miktarı (pişme kaybı), makarnanın değerlendirilmesinde en önemli kalite kriterlerinden birisidir. İyi kaliteli bir makarnanın pişirme sırasında dağılıp parçalanmaması, şeklini koruması ve diri özellikte olması, dolayısıly suya geçen madde miktarının az olmas1 istenmektedir (Köksel vd., 2000). Suya geçen madde miktarının yüksek olması nişastanın fazla çözündüğünü ve makarnanın pişme toleransının düşük olduğunu ifade etmektedir. Farklı oranlarda arpa unu içeren spagetti örneklerinin pişme kaybı değerleri \%7.69 ile \%9.28 arasında değişmiş olup kontrol örneğinden yüksek bulunmuştur. Arpa katkı oranı arttıkça suya geçen madde miktarında da artıs olmuştur $(P$ $\leq 0.05$ ). İrmiğe arpa unu katulması ile formülasyonda zayıf bir gluten ağının oluşması pişme kaybına neden olmuş olabilir. Bu durum birçok araştırmacının (Nasehi vd., 2009; Doxastakis vd., 2007; Manthey ve Hall, 2007; Basman vd., 2006; Manthey vd., 2004) bulgularıly benzerlik göstermiştir.

TOM analizi, pişmiş spagettinin yüzeyinde bulunan ve yikama suyuna geçen nişasta ve diğer organik maddelerin belirlenmesi esasına dayanır. Makarna yüzeyinde fazla miktarda madde bulunması TOM değerinin yüksek olması anlamina gelmektedir (D’Egidio ve Nardi, 1996). $\mathrm{Bu}$ analizi geliştirerek değerlendirme kriterlerini belirleyen araştırıcılar tarafindan spagetti kalitesi eğer TOM değeri 1.4'ten küçükse çok iyi, 1.4-2.1 arasında ise iyi ve 2.1 den büyükse düşük kaliteli şeklinde ifade edilmiştir (D’Egidio vd., 1982). Aynı araşturıcilar ve diğer bazı araştırıcılar TOM değeri ile duyusal testler arasında önemli düzeyde korelatif ilişkinin bulunduğunu bildirmişlerdir (Aktan vd., 1993). Çizelge 4'e bakıldığında TOM değerleri 1.37 ile 1.70 arasında değişmiş ve arpa katkılı spagetti örneklerinde TOM miktarı kontrolden daha yükssek bulunmuştur. En düşük TOM değeri (\%1.37) kontrol örneğinde belirlenmiştir. Ozderen vd. (2008) Svevo durum buğday çeşidinin irmiğinden ürettikleri spagettide TOM değerini 1.27 olarak saptamışlardır. TOM değerinin yüksek çıkmasının arpa unu ilavesi makarnalarda gluten ağının zayıflamasından dolayı pişme sırasında suya daha fazla madde geçişinden kaynaklandığı düşünülmektedir.

\section{Spagetti örneklerinin tekstürel özellikleri}

Çalışmada pişmemiş spagetti örneklerinin kırllganlık özelliği, pişmiş spagetti örneklerinin ise Tekstür Profil Analzi (TPA) metodu kullanilarak sertlik, yapışkanlık, elastiklik ve çiğnenebilirlik özellikleri incelenmiştir. Değişik oranlarda arpa unu kattlarak üretilen spagetti örneklerinin tekstür özelliklerine ilişkin bulgular Çizelge 5'te verilmiştir. Çizelgeden de görülebileceği gibi arpa unu ilave oranının artışına bağlı olarak kırılganlık değerlerinin arttı̆ı (uygulanan kuvvetin az olması) saptanmıştur. Saptanan bu değişimler istatistiksel olarak da önemli bulunmuştur ( $P \leq 0.05)$. Değerlere bakıldığında en kırılgan örneğin \%50 arpa unu katkılı örneğin, en az kırılgan örneğin ise kontrol örneğinin olduğu belirlenmiştir. Arpa unu katk1lı örneklerin daha kırilgan olması kepek içermesinden dolayı spagetti çubuklarının sikı yapısının bozulmasıyla açıklanabilir.

Makarna sertliği pişme sırasında nişasta granüllerinin hidrasyonu ve daha sonra kısmen denatüre olmuş protein ağı içerisine gömülmesiyle ilişkilendirilebilen bir kavramdır (Brennan vd., 2004). Çizelge 5 incelendiğinde arpa unu katkilı spagettilerin sertliği katkı oranının artışına bağlı olarak düşmüştür $(P \leq 0.05)$. Bu durum literatürle (Cleary ve Brennan, 2006; Manthey ve Schorno, 2002; Marconi vd., 2000) de uyum içerisinde bulunmuştur. Sertlik değerindeki azalma spagetti 
formülasyonuna arpa katilmasiyla gluten kuvvetinin azalmasıyla açılanabilir. Arpa unu ilave oranının artışına bağlı olarak spagetti örneklerinin sertliği $33.47 \quad \mathrm{~N}$ 'dan $28.02 \quad \mathrm{~N}$ 'a düşmüş ve tüm örneklerin sertlik değerleri kontrol örneğinden düşük bulunmuş̧tur. Kontrole en yakın sertliğe \%10 arpa unu katkilı spagetti örneği sahip olmuştur.

Çizelge 5. Spagetti örneklerinin tekstürel özellikleri*

Table 5. Textural properties of spaghetti samples*

\begin{tabular}{|c|c|c|c|c|c|c|}
\hline \multirow{2}{*}{$\begin{array}{l}\text { Özellikler } \\
\text { Properties }\end{array}$} & \multicolumn{6}{|c|}{$\begin{array}{l}\text { Tam arpa unu oran1 }(\%) \\
\text { Whole barley flour ratio }(\%)\end{array}$} \\
\hline & 0 & 10 & 20 & 30 & 40 & 50 \\
\hline $\begin{array}{l}\text { Kurllganlik } \\
(\mathrm{N})^{* *} \\
\text { Fracturability }{ }^{* *}\end{array}$ & $1.83 \pm 0.13^{\mathrm{a}}$ & $1.54 \pm 0.02^{\mathrm{ab}}$ & $1.41 \pm 0.08^{\mathrm{bc}}$ & $1.25 \pm 0.16^{\mathrm{bc}}$ & $1.19 \pm 0.13^{c}$ & $1.11 \pm 0.07 \mathrm{c}$ \\
\hline $\begin{array}{l}\text { Sertlik }(\mathrm{N}) \\
\text { Hardness }\end{array}$ & $38.54 \pm 0.73^{a}$ & $33.47 \pm 0.45^{b}$ & $31.79 \pm 0.80^{c}$ & $29.77 \pm 0.62^{\mathrm{cd}}$ & $28.81 \pm 0.87^{\mathrm{d}}$ & $28.02 \pm 0.52^{\mathrm{d}}$ \\
\hline $\begin{array}{l}\text { Yapışkanlik } \\
\text { Adhesiveness }\end{array}$ & $-0.65 \pm 0.03^{a}$ & $-0.76 \pm 0.04^{b}$ & $-0.83 \pm 0.01 \mathrm{bc}$ & $-0.88 \pm 0.01^{\mathrm{cd}}$ & $-0.96 \pm 0.06^{\mathrm{d}}$ & $-1.07 \pm 0.06^{\mathrm{e}}$ \\
\hline $\begin{array}{l}\text { Esneklik } \\
\text { Springiness }\end{array}$ & $0.94 \pm 0.01^{\mathrm{a}}$ & $0.94 \pm 0.01^{\mathrm{a}}$ & $0.94 \pm 0.01^{\mathrm{a}}$ & $0.95 \pm 0.00^{\mathrm{a}}$ & $0.94 \pm 0.00^{\mathrm{a}}$ & $0.94 \pm 0.01^{\mathrm{a}}$ \\
\hline $\begin{array}{l}\text { Ciğnenebilirlik } \\
\text { Chewiness }\end{array}$ & $28.79 \pm 1.13^{\mathrm{a}}$ & $24.86 \pm 3.68^{\mathrm{ab}}$ & $25.93 \pm 1.47^{\mathrm{ab}}$ & $22.85 \pm 1.05^{\mathrm{b}}$ & $21.41 \pm 1.62^{\mathrm{b}}$ & $21.51 \pm 0.30^{\mathrm{b}}$ \\
\hline
\end{tabular}

${ }^{*}$ Aynı satırda farklı harflerle gösterilen ortalamalar arasındaki fark istatistiksel olarak önemlidir $(P \leq 0.05)$

*The difference between the means shown with different letters on the same line is statistically significant $(P \leq 0.05)$

${ }^{* *}$ Pişmemiş makarna örneklerinde belirlenmiştir.

${ }^{* *}$ It was determined in uncooked pasta samples.

Yapışkanlık (adhesiveness), pişmiş makarnanın damak, dil, diş ve parmaklara yapışma durumu olarak ifade edilir (D’Egidio ve Nardi, 1996). Çizelgeden de görülebileceği gibi arpa unu katkıll spagetti örneklerinin yapışkanlığı katkı oranının artışına bağlı olarak artmıştır (değerin eksi olarak sıfirdan uzaklaşması). Değerlerdeki bu değişim istatistiksel olarak da önemli bulunmuştur ( $P$ $\leq 0.05)$. Arpanın kabuğunun soyularak spagettiye katılması ile örneklerin yapışkanlığında azalma saptamıştur. \%10 arpa unu katkılı spagetti örneğinde yapışkanlık değeri -0.76 iken \%50 arpa unu katkılı örnekte bu değer -1.07'ye yükselmiştir. $\mathrm{Bu}$ yükselmenin suya geçen madde miktarındaki artıştan dolayı meydana geldiği düşünülmektedir. Ayrıca bu sonuçlar zenginleştirilmiş makarna ile ilgili yapılan çalışmalarla (Petitot vd., 2010; Wood, 2009; Cleary ve Brennan, 2006) benzerlik göstermiştir.

Esneklik (springiness), bir spagetti örneğine deforme edici gerilme kuvveti uygulanı kaldırıldığında deforme olmuş makarnanın ilk durumuna geri dönme derecesini ifade eder
(D'Egidio ve Nardi, 1996). Arpa unu ilave oranının artışına bağlı olarak örneklerin elastiklik değerleri birbirine yakın bulunmuştur $(P>0.05)$.

Çizelge 5'ten arpa unu katkılı spagetti örneklerinin çiğnenebilirlik değerlerine bakıldığında kontrol örneğine göre düşük olduğu görülmektedir. Yani spagetti örnekleri arpa katkısı ile daha kolay çiğnenebilir özellik kazanmıştır. Arpa unu ilave oranının artışına bağlı olarak değerler önemli düzeyde azalmıştır $(P \leq 0.05)$. Sertlik ile kıvam elastikiyete bağlı bir parametredir (D'Egidio ve Nardi, 1996). Bu nedenle spagetti örneklerinin çiğnenebilirlik değerleri sertlik değerleriyle paralellik göstermiştir.

\section{Spagetti örneklerinin duyusal özellikleri}

Arpa unu katkilı spagetti örneklerinin duyusal değerlendirmesi D'Egidio vd. (1982) ve Cubadda (1988) tarafindan önerilen yöntemlerden yararlanilarak eğitimli 3 panelist tarafindan yapılmış ve sonuçlar Çizelge 6'da verilmiştir. Duyusal analiz sonuçlarına göre örneklerin yapışkanlık, sertlik ve kümeleşme özelliklerine 
arpa unu ilave oranının etkili olduğu gözlenmiştir $(P \leq 0.05)$. Duyusal analizde yapışkanlık, pişmiş makarnanın parmaklara yapışma durumu olarak incelenmiştir. Çizelge 6'dan da görülebileceği arpa unu ilave oranı arttıkça spagetti örneklerinin yapışkanlık puanlanının azaldığı (yapışkanlığının arttığ1) saptanmıştır. En yapışkan spagetti örneği \%50 arpa unu katkılı örnek olurken, yapışkanlığ1 en az olan örnek kontrol örneği olmuştur.

Çizelge 6. Spagetti örneklerinin duyusal özellikleri*

Table 6. Sensory properties of spaghetti samples*

\begin{tabular}{|c|c|c|c|c|c|c|}
\hline \multirow{2}{*}{$\begin{array}{l}\text { Özellikler** } \\
\text { Properties* }\end{array}$} & \multicolumn{6}{|c|}{$\begin{array}{l}\text { Tam arpa unu oranı }(\%) \\
\text { Whole barley flour ratio }(\%)\end{array}$} \\
\hline & 0 & 10 & 20 & 30 & 40 & 50 \\
\hline $\begin{array}{l}\text { Yapışkanlik } \\
\text { Stickiness }\end{array}$ & $55.00 \pm 2.50^{\mathrm{a}}$ & $45.83 \pm 1.4^{b}$ & $45.00 \pm 0.00^{\mathrm{b}}$ & $43.33 \pm 1.44^{b}$ & $40.83 \pm 1.44^{b c}$ & $38.33 \pm 2.89 c$ \\
\hline $\begin{array}{l}\text { Sertlik } \\
\text { Hardness }\end{array}$ & $65.83 \pm 1.44^{a}$ & $60.00 \pm 2.50^{\mathrm{b}}$ & $57.50 \pm 2.50^{\mathrm{bc}}$ & $55.00 \pm 2.50^{\mathrm{bc}}$ & $53.33 \pm 2.89 \mathrm{bc}$ & $49.17 \pm 3.82^{c}$ \\
\hline $\begin{array}{l}\text { Kümeleşme } \\
\text { Bulkiness }\end{array}$ & $50.83 \pm 1.44^{a}$ & $44.17 \pm 5.77^{b}$ & $41.67 \pm 6.29 \mathrm{bc}$ & $39.17 \pm 6.29^{\mathrm{bc}}$ & $37.50 \pm 5.00^{c}$ & $35.83 \pm 6.29^{d}$ \\
\hline
\end{tabular}

${ }^{*}$ Aynı satırda farklı harflerle gösterilen ortalamalar arasındaki fark istatistiksel olarak önemlidir $(P \leq 0.05)$

${ }^{*}$ The difference between the means shown with different letters on the same line is statistically significant $(P \leq 0.05)$

**Puanlama her özellik için 100 puan üzerinden yapılmıştır.

${ }^{* *}$ Scoring was made over 100 points for each feature.

Sertlik, duyusal olarak makarnayı 1sırmak için gerekli kuvvet olarak tanımlanmaktadır. Arpa katkılı spagettilerin sertlik puanlarına bakıldığında ilave oranının artışına bağlı olarak azalmışır. En yüksek sertlik puanını 65.83 ile kontrol örneği alırken, en düşük sertlik puanını 49.17 ile $\% 50$ arpa unu ilaveli spagetti örneği almıştr.

Kümeleşme, pişmiş makarnanın birbirine yapışma oranıdır. Yapışkanlıkla ilgili bir parametredir (D’Egidio ve Nardi, 1996). Çizelge incelendiğinde örneklerin kümeleşme puanı yapışkanlık puanıyla paralellik göstermiştir. Yani katkı oranının artışıla örneklerin kümeleşme durumu artmıştır (Verilen puanın sıfıra doğru yaklaşması kümeleşmenin yüksek olduğunu gösterir). Kümeleşme puanı açısından en yüksek puanı (kümeleşme durumu en az) kontrol örneği alırken, en düşük puanı (kümeleşme durumu en fazla) \%50 arpa unu katkılı spagetti örneği almıștır. Çalışmada arpa unu katk1lı spagetti örneklerinde bulunan duyusal özellik sonuçları daha önce yapılan çalışmalarla (Basman vd., 2006; Manthey ve Schorno, 2002; Marconi vd., 2000) benzerlik göstermiştir.

\section{SONUÇ}

Elde edilen veriler 1şığında;
Arpanın makarnada doğal bir katkı maddesi olarak belli oranlarda kullanılması ile kabul edilebilir nitelikte makarna yapılabildiği,

Arpa unu katkılı spagetti örneklerinde makarna kalitesi ve renk değeri $\left(b^{*}\right)$ irmikten yapilan spagetti örneğinin değerlerinden daha düşük bulunmasina karssın, arpa ununun belli oranlarda katılması ile kabul edilebilir kalitede spagetti üretilebildiği,

Arpa unu katk1lı tüm spagetti örneklerinde fonksiyonel bileşenler irmikten yapılan kontrol örneğine göre daha yüksek bulunduğu,

Makarna kalitesi ve renginin (b*) kabul edilebilirliği ve ticari olarak üretim dikkate alındığında makarna formülasyonuna tam arpa unu ilavesinin uygun olduğu sonucuna varılmıştur.

Böylece besinsel lif içeriği özellikle $\beta$-glukan içeriği yüksek olan ve ülkemizde genellikle hayvan yemi olarak ve biracılıkta değerlendirilen arpanın makarna üretiminde kullanılması ile belirli sağlık sorunu olan kişilerin ihtiyaçlarına da hizmet edilmiş olacaktır. Makarna örneklerinde arpa unu oranının artışına bağlı olarak fitik asit içeriği artmış olması olumlu bir durum olarak düşünülmektedir. Çünkü, son yıllarda fitik asidin insan sağlığ1 üzerindeki etkisi konusunda yapılan çalışmalar fitik asidin antikanserojen ve antioksidan etkisi 
nedeniyle pozitif etkilere de sahip olduğunu göstermiş̧tir (Tolay vd., 2005). Ayrıca bu çalışmanın, kullanılan arpanın değişik fraksiyonlarının da kullanılarak değişik gıdalarda yapılacak araştırmalara ışı1k tutacağı umulmaktadır.

\section{TEŞEKKÜR}

Bu makale Harran Üniversitesi Bilimsel Araştırma Projeleri Koordinasyon Birimi tarafindan 852 proje numarası ile desteklenen "Arpa Unu ile Zenginleștirmenin Makarnanın Bazı Besinsel ve Kalite Özelliklerine Etkisi” başlıklı Doktora Tezi esas alınarak hazırlanmıştır. Desteklerinden dolayı Harran Üniversitesi Rektörlüğüne ve BAP Koordinasyon Birimi'ne teşekkür ederiz.

\section{ÇIKAR ÇATIŞMASI BEYANI}

Yazarlar, bu makale ile ilgili başka kişi veya kurumlar ile çıkar çatışması olmadığını beyan eder.

\section{YAZAR KATKILARI}

MK ve AA, araşturmayı tasarladı. MK, makalenin metodoloji, biçimsel analiz, istatistiksel analiz, yazma-orijinal taslak, yazma-inceleme, düzenleme ve görselleştirmesine katk1 sunmuştur. AA, proje yönetimi, kavramsallaştırma, metodoloji, biçimsel analiz, yazma- orijinal taslak, yazma-inceleme ve düzenleme, görselleştirme ve danışman olarak katkı sağlamıştur. Yazarlar makalenin son halini okudu ve onayladi.

\section{KAYNAKLAR}

AACC, (2000). Approved Methods of the American Association of Cereal Chemists. Approved Methods of Analyses, 10th Edition, The Association: St. Paul, MN.

Aktan, B., Atli, A., Tuncer, T. (1993). Makarnanin pişme kalitesinin tesbitinde kullanılan yöntemler arasındaki ilişkiler üzerine bir araştırma. Makarnalık Buğday ve Mamülleri Simpozyumu, 30 Kasım-3 Aralık, Ankara, Türkiye, s. 330-334

Anonymous, (2007a). Healthgrain Background, http://www.healthgrain.org/pub/chapterone.php.

Anonymous, (2007b). Healthful whole grains. http://www.oznet.k-

state.edu/humannutrition/mf2560.pdf.
Anonymous, (2002a). Türk gida kodeksi. Makarna tebliği (2002/20). Tarım ve Köyişleri Bakanlığı. 5 Mart 2002 tarih ve 24686 sayll Resmi Gazete, Ankara.

Anonymous, (2002b). Türk g1da kodeksi. İrmik tebliği (2002/21). Tarım ve Köyişleri Bakanlığı. 5 Mart 2002 tarih ve 24686 sayll Resmi Gazete, Ankara.

Anonymous, (1990). Official Methods of the Association of Official Analytical Chemists, 15th Edition, Arlington, VA:AOAC, pp. 152-169.

Baik, B.K., Ullrich, S.E. (2008). Barley for food: Characteristics improvement and renewed interest. $J$ Cereal Sci, 48(2): 233-242. doi:10.1016/j.jcs.2008.02.002

Bashir, K., Aeri, V., Masoodi, L. (2012). Phiycchemical and sensory characteristics of pasta fortified with chickpea flour and defatted soy flour. IOSR J Environ Sci, Toxicol Food Technol, 1(5): 34-39. ISSN: 2319-2402, ISBN: 2319-2399

Basman, A., Koksel, H., Atli, A. (2006). Effects of increasing levels of transglutaminase on cooking quality of bran supplemented spaghetti. Eur Food Res Technol, 223(4): 547-551. doi:10.1007/s00217005-0235-3

Bergman, C.J., Gualberto, D.G., Weber, C.W. (1994). Development of a high-temperature-dried soft wheat pasta supplemented with cowpea (Vigna Unguiculata L. Walp) cooking quality, color and sensory evaluation. Cereal Chem, 71(6): 523527.

Bourne, M.C. (1978). Texture profile analysis. Food Technol, 32(7): 62-66

Brennan, C.S., Cleary, L.J. (2005). The potential use of cereal $(1 \rightarrow 3,1 \rightarrow 4)-\beta$-d-glucans as functional food ingredients. J Cereal S $c i, 42(1)$ : 1 13. doi:10.1016/j.jcs.2005.01.002

Chillo, S., Laverse, J., Falcone, P.M., Protopapa, A., Del Nobile, M.A. (2008a). Influence of the addition of buckwheat flour and durum wheat bran on spaghetti quality. J Cereal Sci, 47(2): 144152. doi:10.1016/j.jcs.2007.03.004

Chillo, S., Laverse, J., Falcone, P.M., Del Nobile, M.A. (2008b). Quality of spaghetti in base amaranthus wholemeal flour added with quinoa, 
broad bean and chick pea. J Food Eng, 84(1): 101107. doi:10.1016/j.jfoodeng.2007.04.022

Cleary, L., Brennan, C. (2006). The influence of a $(1-3)(1-4)-\beta$-D-glucan rich fraction from barley on the physico-chemical properties and in vitro reducing sugars release of durum wheat pasta. Int J Food Sci Tecbnol, 41(8): 910-918. doi:10.1111/j.1365-2621.2005.01141.x

Coşkun, Y., İlkan, A., Köten, M., Coşkun, A. (2010). Güneydoğu Anadolu Bölgesinde yetiştirilen farklı makarnalık buğday çeşitlerinin kalite yönünden değerlendirilmesinde $b$ ve $b^{*}$ renk değerlerinin kullanılabilirliğinin incelenmesi. HR.Ü.Z.F.Dergisi, 14(3): 25-29.

Cubadda, R. (1989). Current research and future needs in durum wheat chemistry and technology. Cereal Foods World, 34(2): 206-209.

Dai, F., Wang, J., Zhang, S., Xu, Z., Zhang, G. (2007). Genotypic and environmental variation in phytic acid content and its relation to protein content and malt quality in barley. Food Chem, 105(2):

606-611.

doi:10.1016/j.foodchem.2007.04.019

De Paula, R., Abdel-Aal, E.-S. M., Messia, M. C., Rabalski, I., Marconi, E. (2017). Effect of processing on the beta-glucan physicochemical properties in barley and semolina pasta. J Cereal Sci, 75: 124-131. doi:10.1016/j.jcs.2017.03.030

D’Egidio, M.G., Nardi, S. (1996). Textural measurement of cooked spaghetti. Pasta and Noodle Technology: Edited by James E. Kruger, Robert B. Matsuo and Joel W. Dick. AACC St. Paul Minnesota, U.S.A: AACC Inc., pp. 133-157

D'Egidio, M.G., DeStefanis, E., Fortini, S., Galterio, G., Nardi, S., Sgrulletta, D., Bozzini, A. (1982). Standardization of cooking quality analysis in macaroni and pasta products. Cereal Foods World, 27(8): 367-368. ISSN: 0146-6283

Dendougui, F., Schwedt, G. (2004). In vitro analysis of binding capacities of calcium to phytic acid in different food samples. Eur Food Res Technol, 219(4): 409-415. doi:10.1007/s00217004-0912-7

Doxastakis, G., Papageorgiou, M., Mandalou, D., Irakli, M., Papalamprou, E., D’Agostina, A.,
Resta, D., Boschin, G., Arnoldi, A. (2007). Technological properties and non-enzymatic browning of white lupin protein enriched spaghetti. Food Chem, 101(1): 57-64. doi:10.1016/j.foodchem.2005.12.054

Egli, I., Davidsson, L., Zeder, C., Walczyk, T., Hurrell, R. (2004). Dephytinization of a complementary food based on wheat and soy increases zinc, but not copper, apparent absorption in adults. $J$ Nutr, 134(5), 1077-1080. doi:10.1093/jn/134.5.1077

Gallegos-Infante, J.A., Rocha-Guzman, N.E., Gonzalez-Laredo, R.F., Ochoa-Martinez, L.A., Corzo, N., Bello-Perez, L.A., Medina-TorreS, L., Peralta-Alvarez, L.E. (2010). Quality of spaghetti pasta containing mexican common bean flour (Phaseolus vulgaris L.). Food Chem, 119(4): 15441549. doi:10.1016/j.foodchem.2009.09.040

Giménez, M.A., Drago, S.R., Bassett, M.N., Lobo, M.O., Sammán, N.C. (2016). Nutritional improvement of corn pasta-like product with broad bean (Vicia faba) and quinoa (Chenopodium quinoa). Food Chem, 199: 150-156. doi:10.1016/j.foodchem.2015.11.065

Gül, H. (2007). Mısır ve buğday kepeğinin hamur ve ekmek nitelikleri üzerindeki etkilerinin incelenmesi. Çukurova Üniversitesi Fen Bilimleri Enstitüsü Gıda Mühendisliği Anabilim Dalı, Doktora Tezi, Adana, Türkiye, $232 \mathrm{~s}$.

Güvendi, Ö. (2011). Besinsel lif ve antioksidanca zengin tahıllardan geleneksel yöntem ile erişte üretimi. Abant İzzet Baysal Üniversitesi Fen Bilimleri Enstitüsü Gıda Mühendisliği Anabilim Dalı, Yüksek Lisans Tezi, Bolu, Türkiye, 160 s.

Hailu, F., Merker, A. (2008). Variation in gluten strength and yellow pigment in Ethiopian tetraploid wheat germplasm. Genet Resour Crop Ev, 55(2): 277-285. doi:10.1007/s10722-007-9233-6

Haug, W., Lantzsch, H.J. (1983). Sensitive method for the rapid determination of phytate in cereals and cereal products. I Sci Food Agri, 34(12): 1423-1426. doi:10.1002/jsfa.2740341217

Helm, C.V., de Francisco, A. (2004). Chemical characterization of Brazilian hulless barley varieties, flour fractionation, and protein 
concentration. Scientia Agricola, 61(6): 593-597. doi:10.1590/s0103-90162004000600005

Hurrell, R.F. (2004). Influence of vegetable protein sources on trace element and mineral bioavailabilty. J Nutr, 133(9): 2973S-2977S. doi:10.1093/jn/133.9.2973S

Köksel, H., Sivri, D., Özboy, Ö., Baflman, A., Karacan, H.D. (2000). Hububat Laboratuar El Kitabı. Hacettepe Üniversitesi, Mühendislik Fak. Yayın No: 47, Ankara, Türkiye, 106 s. ISBN: 9754910928, 9789754910926

Köksel, H., Edney, M. J., Özkaya, B. (1999). Barley bulgur: effect of processing and cooking on chemical composition. J Cereal Sci, 29 (2): 185190. doi:10.1006/jcrs.1998.0230

Köksel, H., Atlı, A., Özkaya, H. (1992). Baz1 durum buğday çeşitlerinde yetiştirme yerinin elektroforetik özellikler ve makarna pişme kalitesi üzerine etkileri. Doğa- Turk J Agric For, 16(3): 593605.

Köse, Ö.D.E., Mut, Z. (2019). Yerli ve yabanc1 baz1 arpa (Hordeum vulgare L.) çeşitlerinin mineral madde içerikleri. KSÜ Tarm ve Doğa Derg, 22(5): 671-677. doi:10.18016/ksutarimdoga.vi.523982

Köten, M., Ünsal, A.S., Atl, A. (2014). Türkiye'de üretilen makarnaların bazı kimyasal bileşimlerinin ve pişme kalitelerinin belirlenmesi. Gida, 39(1): 33-40. doi:10.5505/gida.76376

Lee, S.C., Prosky, L., Devries, J.W. (1992). Determination of total, soluble, and insoluble dietary fiber in foods-enzymatic-gravimetric method, mes-tris buffer: collaborative study. $J$ AOAC Int, 75(3): 395-416. doi:10.1093/jaoac/75.3.395

Madenci, A.B. (2017). Besinsel lif ve antioksidan maddece zengin bileşenlerin yaş makarnanın bazı kalite özellikleri ve raf ömrü üzerine etkisi. Necmettin Erbakan Üniversitesi Fen Bilimleri Enstitüsü G1da Mühendisliği Anabilim Dalı, Doktora Tezi, Konya, Türkiye, 203 s.

Manthey, F.A., Hall, C.A. (2007). Effect of processing and cooking on the content of minerals and protein in pasta containing buckwheat bran flour. J Sci Food Agric, 87(11): 2026-2033. doi:10.1002/jsfa.2953
Manthey, F.A., Yalla, S.R., Dick, T.J., Badaruddin, M. (2004). Extrusion properties and cooking quality of spaghetti containing buckwheat bran flour. Cereal Chem, 81(2): 232-236. doi:10.1094/cchem.2004.81.2.232

Manthey, F.A., Schorno, A.L. (2002). Physical and cooking quality of spaghetti made from whole wheat durum. Cereal Chem, 79(4): 504-510. doi:10.1094/cchem.2002.79.4.504

Marconi, E., Graziano, M., Cubadda, R. (2000). Composition and utilization of barley pearling byproducts for making functional pastas rich in dietary fiber and $\beta$-glucans. Cereal Chem, 77(2): 133-139. doi:10.1094/cchem.2000.77.2.133

Marconi, E., Carcea, M., Graziano, M., Cubadda, R. (1999). Kernel properties and pasta-making quality of five european spelt wheat (Triticum spelta L.) cultivars. Cereal Chem, 76(1): 25-29. doi:10.1094/cchem.1999.76.1.25

Matsuo, R.R. (1996). Durum wheat: its unique pasta-making properties. In: Wheat Production, Properties and Quality by W. Bushuk and V.F. Rasper. Published by Blacie Acedemic and Professional, an Imprint of Chapman and Hall, p. 173.

Mccleary, B.V., Mugford, D.C. (1992). Interlaboratory evaluation of $\beta$-glucan analysis methods. "The changing role of oats in human and animal nutrition". Proceedings of the Fourth International Oat Conference, October 19-23, Adelaide, Australia.

McCleary, B.V., Cood, R. (1991). Measurement of (1-3), (1-4)- $\beta$-D-glucan in barley and oats: a streamlined enzymic prodecure. J Sci Food Agric, 55: 303-312. doi:10.1002/jsfa.2740550215

McCleary, B.V., Glennie-Holmes, M. (1985). Enzymic quantification of (1-3), (1-4)- $\beta$-D-glucan in barley and malt. J Inst Brew, 91(5): 285-295. doi:10.1002/j.2050-0416.1985.tb04345.x

Nasehi, B., Mortazavi, S.A., Razavi, S.M.A., Mahallati, M.N., Karim, R. (2009). Optimization of the extrusion conditions and formulation of spaghetti enriched with full-fat soy flour based on the cooking and color quality. Int J Food Sci Nutr, 60(sup4): 205-214. doi:10.1080/ 09637480902787601 
O'Dell, B.L., De Boland, A.R., Koirtyohann, S.R. (1972). Distribution of phytate and nutritionally important elements among the morphological components of cereal grains. J Agric Food Chem, 20(3): 718-723. doi:10.1021/jf60181a021

Ozderen, T., Olanca, B., Sanal, T., Ozay, D.S., Koksel, H. (2008). Effects of suni-bug (Eurygaster spp.) damage on semolina properties and spaghetti quality characteristics of durum wheats (Triticum durum L.). J Cereal Sci, 48(2): 464470. doi:10.1016/j.jcs.2007.11.004

Panfili, G., Fratianni, A., Criscio, T. D., Marconi, E. (2008). Tocol and $\beta$-glucan levels in barley varieties and in pearling by-products. Food Chem, 107(1):

84-91.

doi:10.1016/j.foodchem.2007.07.043

Petitot, M., Boyer, L., Minier, C., Micard, V. (2010). Fortification of pasta with split pea and faba bean flours: Pasta processing and quality evaluation. Food Res Int, 43(2): 634-641. doi:10.1016/j.foodres.2009.07.020

Pınarlı, İ., İbanoğlu, S.., Öner, M.D. (2004). Effect of storage on the selected properties of macaroni enriched with wheat germ. J Food Eng, 64(2): 249256. doi:10.1016/j.jfoodeng.2003.10.005

Prosky, L., Asp, N.-G., Schweizer, T. F., Devries, J. W., Furda, I. (1992). Determination of insoluble and soluble dietary fiber in foods and food products: Collaborative study. J AOAC Int, 75(2): 360-367. doi:10.1093/jaoac/75.2.360

Prosky, L., Asp, N.-G., Schweizer, T. F., Devries, J. W., Furda, I. (1988). Determination of insoluble, soluble and total dietary fiber in foods and food products: Interlaboratory study. $J$ AOAC Int, 71(5): 1017-1023. doi:10.1093/jaoac/71.5.1017

Silva, E.M.M. da, Ascheri, J.L.R., Ascheri, D.P.R. (2016). Quality assessment of gluten-free pasta prepared with a brown rice and corn meal blend via thermoplastic extrusion. LWT - Food Sci Technol, 68: 698-706. doi:10.1016/j.lwt.2015.12.067

Slavin, J. (2004). Whole grains and human health. Nutr Res Rev, 17(1): 99-110. doi:10.1079/nrr200374
Sozer, N., Dalgyç, A.C., Kaya, A. (2007). Thermal, textural and cooking properties of spaghetti enriched with resistant starch. J Food Eng, 81(2): 476-484. doi:10.1016/j.jfoodeng.2006.11.026

Sözer, N. (2006). Dirençli nişasta katkı1ı spagettinin reolojik özellikleri. Gaziantep Üniversitesi Fen Bilimleri Enstitüsü G1da Mühendisliği Anabilim Dalı, Doktora Tezi, Gaziantep, Türkiye, 124 s.

Sungur, B., Ercan, R. (2003). Tam buğday unu ekmeklerinde suda çözünebilir gamların kullanım olanaklar1. Gida, 28(5): 453-460. Retrieved from https://dergipark.org.tr/tr/pub/gida/issue/697 8/92991

Tolay, İ., Aytaç, Z., Gülmezoğlu, N., Budak, Z., Kınac1, G., Kınac1, E. (2005). Tahıllarda fitik asit içeriği ve beslenme açısından önemi. Türkiye VI. Tarla Bitkileri Kongresi, 5-9 Eylül 2005, Antalya, Türkiye, s. 1187-1192.

Torres, A., Frias, J., Granito, M., Vidal-Valverde, C. (2007). Germinated Cajanus cajan seeds as ingredients in pasta products: Chemical, biological and sensory evaluation. Food Chem, 101(1): 202-211. doi:10.1016/j.foodchem. 2006.01.018

Wood, J.A. (2009). Texture, processing and organoleptic properties of chickpea-fortified spaghetti with insights to the underlying mechanisms of traditional durum pasta quality. $J$ Cereal Sci, 49(1): 128-133. doi:10.1016/j.jcs. 2008.07.016

Yalçın, E., Çelik, S. (2006). Kavuzsuz arpa proteinlerinin baz1 fonksiyonel özelliklerinin incelenmesi. Türkiye 9. Gida Kongresi, 24-26 Mayıs, Bolu, Türkiye, s. 657-660

Yeung, J., Vasanthan, T. (2001). Pearling of hullless barley: product composition and gel color of pearled barley flours as affected by the degree of pearling. J Agric Food Chem, 49(1): 331-335. doi:10.1021/jf000893e

Zhao, Y.H., Manthey, F.A., Chang, S.K.C., Hou, H.-J., Yuan, S.H. (2006). Quality characteristics of spaghetti as affected by green and yellow pea, lentil, and chickpea flours. J Food Sci, 70(6): s371s376. doi:10.1111/j.1365-2621.2005.tb11458.x 